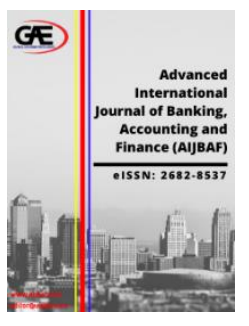

\author{
ADVANCED INTERNATIONAL JOURNAL OF \\ BANKING, ACCOUNTING AND FINANCE \\ (AIJBAF) \\ www.aijbaf.com
}

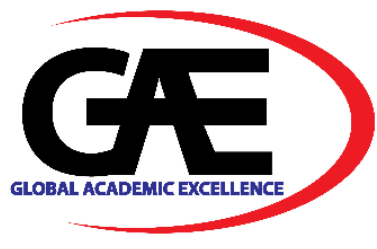

\title{
NON-SHARI'AH COMPLIANT INCOME GAIN OF ISLAMIC BANKS AND ITS IMPACT ON CUSTOMERS TRUST AND COMMITMENT: A QUALITATIVE APPROACH
}

\author{
Muhammad Usman ${ }^{1}$, Anwar Allah Pitchay ${ }^{2 *}$, Eliza Nor ${ }^{3}$, Ema Izati $^{4}$, Munazza Zahra $^{5}$
}

$1 \quad$ School of Management, Universiti Sains Malaysia

Email: muhammad_usman@student.usm.my

2 School of Management, Universiti Sains Malaysia

Email: anwarap@usm.my

3 School of Management, Universiti Sains Malaysia

Email: eliza.nor@usm.my

$4 \quad$ School of Management, Universiti Sains Malaysia

Email: emazull@usm.my

5 School of Management, Universiti Sains Malaysia

Email: munazza.zahra89@gmail.com

Corresponding Author

Article Info:

\section{Article history:}

Received date: 19.09 .2021

Revised date: 12.10 .2021

Accepted date: 01.11.2021

Published date: 01.12.2021

\section{To cite this document:}

Usman, M., Pitchay, A. A., Nor, E., Izati, E., \& Zahra, M. (2021). NonShari'ah Compliant Income Gain Of Islamic Banks And Its Impact On Customers Trust And Commitment: A Qualitative Approach. Advanced International Journal of Banking, Accounting, and Finance, 3 (9), 1522.

DOI: $10.35631 /$ AIJBAF.39002.

This work is licensed under $\underline{\text { C B BY } 4.0}$

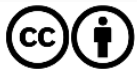

Abstract:

The aim of this paper is to focus on the impact of non-sharia compliant income of Islamic banks on customers' trust and commitment. The research work has followed the qualitative strategy as it has worked on secondary qualitative data. Books, journals, and credible websites have been reviewed as the primary methods of collecting secondary qualitative data. Thematic analysis has been used to analyse the gathered data. According to the findings of this paper, those banks which are not focusing on shariah compliance cannot achieve the trust of the customers which ultimately leads to a lack of customers commitment.

Keywords:

Non-Shariah Compliance, Income, Trust, Commitment, Customers 


\section{Introduction}

In Islamic Banking, every transaction must be made in compliance with shariah. Cheong (2021) has opined that requirements of shariah-compliance present unique conditions for examining firms' performance. In most of the Islamic banks, non-shariah compliant income is accepted which leads to dissatisfaction among account holders. This research particularly rises from this ground to investigate the issue.

The issue is the customers' dissatisfaction on Islamic Banks that do not comply with shariah guidance. This is an issue because Muslim people are encouraged to use those banks that comply with Shariah principles. There are a total of 428 commercial Islamic banks across the world (statista.com, 2021). Now the issue is to understand why most of these banks do not comply with shariah banking. This research sheds light on how customers trust and commitment gets hampered while getting services from banks that do not comply with shariah principles.

The questions that have set direction for the research-investigation are:

- What are the principles governing Islamic banking and finance?

- What are the impacts of non-shari'ah compliant income gain of Islamic banks on customers' commitment and trust?

Compilation of this work helps to understand the extent to which trust and commitment of customers get hampered in case their respective banks do not comply with shariah principles. Ahmed, Islam \& Mohiuddin (2017) have mentioned that Islamic banks operate activities in accordance with "Islamic Shariah Principles". Therefore, doing research on the given topic is always beneficial to understand the consequences that Islamic banks face or might face in case they do not operate business as per shariah principles.

\section{Literature Review}

This section of the research paper deals with actual phenomena of the topic. In doing so, principles governing operations of the Islamic Banking Industry have been described with an eye on "non-Shariah compliant". A significant part focuses on the after-effect of not complying with shariah principles. 


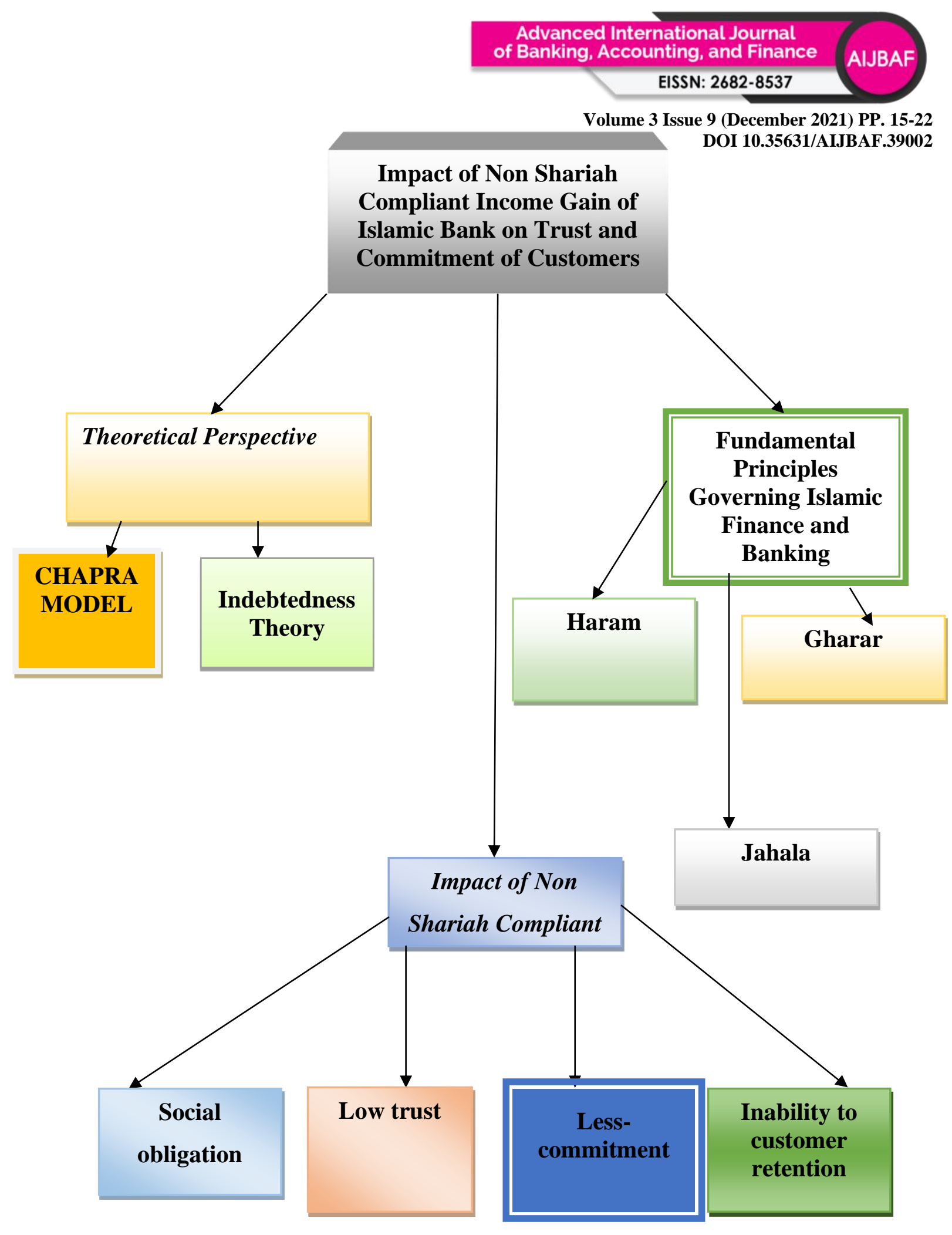

(Source: Self-developed)

Figure 2.1: Conceptual Framework

The method applied for operating Islamic Bank is abided by Shariah Law. BBC (2021) has reported that Shariah Law forms the "Islamic Legal System". This law leads Islamic people under the guidance of some principles to act ethically. Under the influence of this law, principles that governing Islamic finance and banking today are: 
Volume 3 Issue 9 (December 2021) PP. 15-22 DOI 10.35631/AIJBAF.39002

Haram that is imposed for restricting the act of "giving and receiving of riba". Riba is the usury or interest paid to depositors and interest levied from dund users.

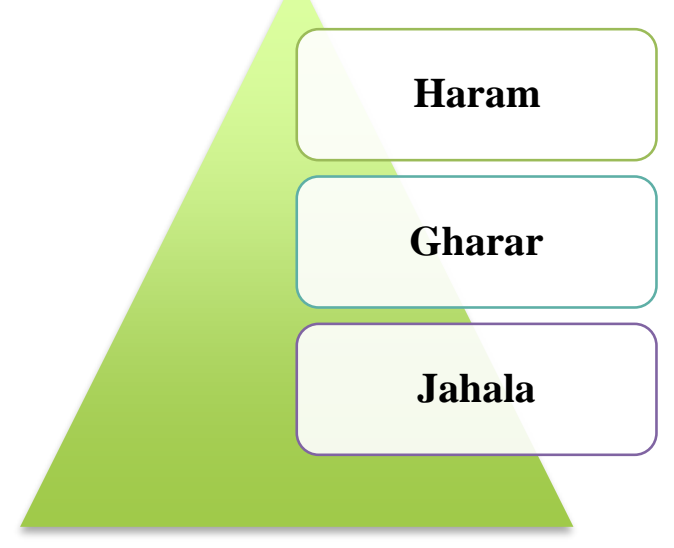

Figure 2.2: Fundamental Principles Governing Islamic Finance and Banking (Source: Self-developed)

- Gharar is a shariah principle that refers to an uncertain contract (Utami \& Slamet, 2021). It is considered as a risk that is equivalent to "zero-sum game" having uncertain payoffs.

- Jahala is also a shariah principle that means ignorance. In Islamic Banking, Jahala sales are considered as invalid as the information asymmetry affords an unfair advantage to parties involved.

\section{Non-Shariah Compliance}

Shariah compliant means a firm's compilation with Islamic principles in operational activities. On the other hand, Non-Shariah compliant money refers to the adopted practices that are considered impressive according to the "Islamic Legal System". Money or properties involved in non-sharia compliance are forbidden property gained through "non-shariah means" (My Government, 2021).

\section{Impact of Non Shariah Compliant Income Gain of Islamic Bank on Trust and Commitment of Customers}

Both trust and commitment is considered as a multifaceted phenomenon. Therefore, driven by religiosity, trust and commitment of customers' commitment of Islamic Bank depends on the ethics that those financial institutes maintain in operation. Suhartanto, Farhani \& Muflih (2018) have mentioned that religiosity is a stronger element in influencing behaviours of customers. These religious minded Muslim people finds religiosity among their preferred banking organization's operations.

\section{Impact of Non-Sharia coomliant}

\section{- Negative customer trust \& commitment}

Figure 2.3: Impact of Non Shariah Compliant Income Gain of Islamic Bank on Trust and Commitment of Customers

(Source: eprints.bournemouth.ac.uk, 2021) 
Volume 3 Issue 9 (December 2021) PP. 15-22

DOI 10.35631/AIJBAF.39002

Here, Islamic Banks adopt all the principles of Shariah law to show that their operations are complied with the laws of Allah, the unparalleled Islamic God. Islamic people are encouraged to use banks that follow these principles (eprints.bournemouth.ac.uk, 2021). Banking and financial institutions that gain non-shariah compliant income create dissatisfaction among customers. This is due to the fact that trust and commitment in Islamic people are enhanced by the rules of Shariah Law. In case a bank does not follows such rules, Muslim people finds operations of that bank inappropriate and impermissible.

\section{Theoretical Perspectives}

\section{CHAPRA'S Model}

\section{Indebtedness Theory}

(Source: Self-developed)

\section{Figure 2.4: Theoretical Perspectives}

Chapra's model is one of those two core models used in Islamic Banks. This model is used to favour profit maximization and to promote a "greater social welfare responsibilities" upon Islamic Banks (core.ac.uk, 2021). Besides this mode, Indebtedness theory is also used in Islamic Banks. This theory establishes certain obligations and rights regarding compliance with Shariah rules (Ahmed et al. 2018). Under the guidance of this theory, conditions that mentioned a person's indebtedness are determined.

This literature focuses on many aspects of non-shariah complaints alongside their impacts on customers' commitment and trust. However, lack of focus on governments' regulations on nonshariah complaints creates the main gap of this piece of research work.

\section{Materials and Methods}

This research work has been developed using positivism philosophy to focus on the factual knowledge of the study. As per the comment of Alharahsheh \& Pius (2020), positivism philosophy focuses on the significant value of the factors given in general. Same approach has been followed here to answer the research question in an objective way. In terms of approach, the research work has followed an inductive approach. Inductive approach draws general conclusion from observation. In this work, conclusion has also been made from in-depth observation made over the collected data. Under the employment of descriptive design, this work has made a description on the data indicating the actual phenomenon of the topic. Descriptive research follows phenomenological approaches (Pradipta, Ummah \& Dewantoro, 2018). Using this phenomenological approach while designing the research, descriptions have been given on the implications of collected data. 


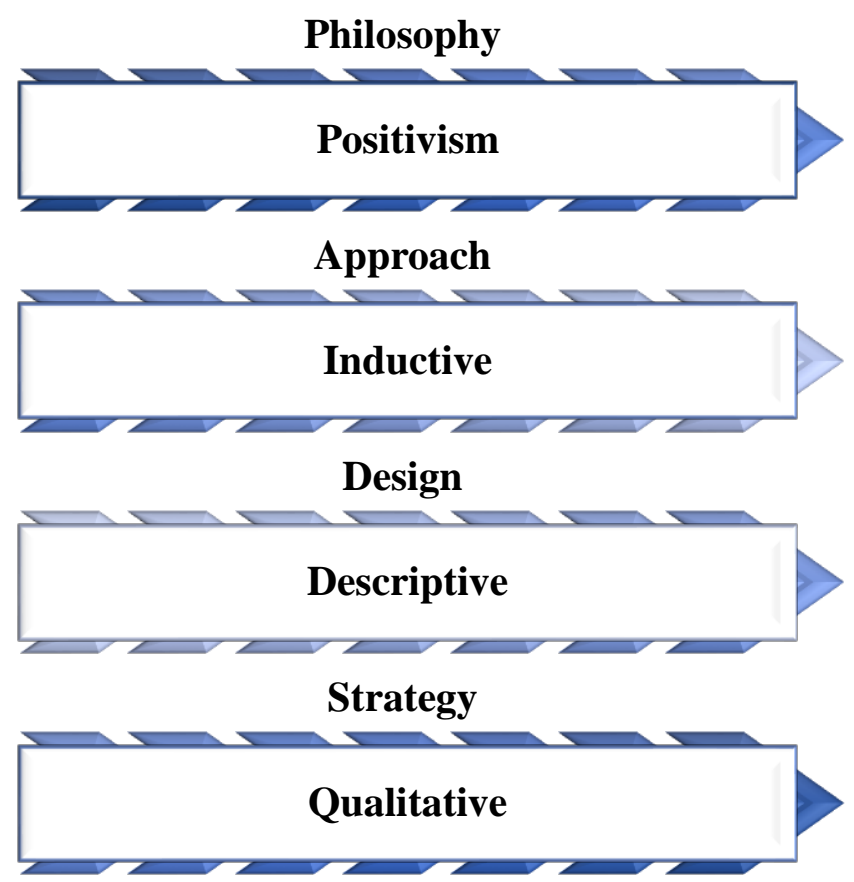

(Source: Self-developed)

Figure 3.1: Research Philosophy, Approach, Design and Strategy

The research work has followed the qualitative strategy as it has worked on secondary qualitative data. Bansal, Smith \& Vaara (2018) have opined that qualitative research provides more insights into the research topic. In order to gain such insights, this work has used literature review as the primary method of collecting secondary qualitative data. Books, journals and credible websites have been reviewed to collect those data. Thematic analysis has been used as the method of data collection.

In order to maintain integrity and transparency while using that data "The Data Protection Act 1988 " has been followed. According to this legislation, data of others must be used "fairly, transparently and lawfully" for personal use (legislation.gov.uk, 2021). Alongside maintaining this ethics, each data has been used by acknowledging the respective authors.

\section{Results}

Using the thematic analysis method, the below-mentioned themes have been developed to showcase the findings over secondary qualitative data:

\section{Theme 1: Non-Shariah Compliant Income of Islamic Banking Negatively Impacts on Customer Trust and Commitment}

Non-shariah compliant Islamic banks could give rise to negative trust and confidence of customers because it is against the religious principles and teachings. This does not stand connected with the concept of avoiding or refraining from Riba. Fianto et al. (2020) mentioned that consumer behaviours are an evolving phenomena and stakeholder theory becomes important here. This is because the relationships of the organization with others are important to maintain functional levels of performance. Brand image of such banks are influenced negatively and they do not sustain in terms of religiously inclined customers. This is because they value service quality, which is clearly not maintained if it is a non-shariah compliant bank. 
Volume 3 Issue 9 (December 2021) PP. 15-22

DOI 10.35631/AIJBAF.39002

Theme 2: Banking Operations Governed by Shariah Principles Satisfy Customers' Trust And Commitment

Islamic followers are governed by religious teachings and principles to engage in activities that are fruitful for their business as well. This makes it important for the banks to gain trust of the customers and commit their loyalty too. According to Haron, Abdul Subar and Ibrahim (2020), shariah principles govern Islamic banks to follow activities that forbid interest (riba), and avoid "gambling (maisir) and speculative trading (gharar)". The "Shariah Advisory Committee (SAC)" provides guidance to the banks to follow shariah principles and maintain customer trust via their activities (Haron, Abdul Subar and Ibrahim, 2020). Thus, banking actions that are influenced by shariah principles affect customer satisfaction positively and thus, create a positive stance for their trust.

\section{Discussion}

The theme 1 shows that customers' trust and commitment is greatly influenced by those operations of Islamic Banks that comply with principles of Shariah. This is due to the fact that Muslim people are encouraged to use services of those specific banks that reflect compliant with Islamic Laws in their operations. Bintoro (2021) has mentioned that Shariah principles address people to embrace humanitarian approaches in their daily doings. On the contrary, theme 2 draws attention to the negative impact of non-shariah compliant on customers' trust and commitment. This occurs because of the religious mind-set of Muslim people that leads them to work with those operations that are permissible according to the Sharia Law.

\section{Conclusion}

This research has reached the understanding that Banking organizations that gain non-shariah compliant income are not effective in fulfilling commitment and trust of their customers. The religious minded Muslim people finds ethics in everything associated with their daily lives. Non-shariah complaints involve activities that are forbidden according to the rules of Islam. As Islamic People want to be ethical while taking services from any financial institutes. This is because the relationships of the organization with others are important to maintain functional levels of performance. Therefore, lack of focusing on shariah principles negatively impacts trust and commitment of customers.

\section{References}

Ahmed, E. R., Alabdullah, T. T. Y., Amran, A., \&Yahya, S. B. (2018). Indebtedness Theory and Shariah Boards: A Theoretical Approach. Global Business and Management Research, 10(1), 127-134.

Ahmed, S., Islam, R., \&Mohiuddin, M. (2017). Service Quality, Shariah Compliance and Customer Satisfaction of Islamic Banking Services in Malaysia. Turkish Journal of Islamic Economics, 4(2), 71-82.

Alharahsheh, H. H., \& Pius, A. (2020). A review of key paradigms: Positivism VS interpretivism. Global Academic Journal of Humanities and Social Sciences, 2(3), 3943.

Bansal, P., Smith, W. K., \&Vaara, E. (2018).New ways of seeing through qualitative research.

BBC. (2021). What is Sharia and how is it applied? BBC.Retrieved on $27^{\text {th }}$ June 2021. Retrieved from: https://www.bbc.com/news/world-27307249

Bintoro, R. W. (2021). BasiCprinCiples of sharia eConomy for CommUnityeConomiC empowerment (stUDy of the sharia prinCiplesappliCation in inDonesia). Problems of Legality, (153).

Copyright $\odot$ GLOBAL ACADEMIC EXCELLENCE (M) SDN BHD - All rights reserved 
Volume 3 Issue 9 (December 2021) PP. 15-22

DOI 10.35631/AIJBAF.39002

Cheong, C. W. (2021). Risk, resilience, and Shariah-compliance.Research in International Business and Finance, 55, 101313.

core.ac.uk. (2021).APPLICABILITY OF CHAPRA'S MODEL OF ISLAMIC BANKING IN NIGERIA.Retrieved on $27^{\text {th }}$ June 2021. Retrieved from: https://core.ac.uk/download/pdf/236413275.pdf

eprints.bournemouth.ac.uk. (2021).Consumer trust and confidence in the compliance of Islamic banks.Retrieved on $27^{\text {th }}$ June 2021. Retrieved from: https://eprints.bournemouth.ac.uk/23242/1/Samreen\%20JFSM\%20Paper\%20submissi on\%20post\%20revisions.pdf

Fianto, B. A., Gan, C., Widiastuti, T., \&Sukmana, R. (2020). Customer loyalty to Islamic banks: Evidence from Indonesia. Cogent Business \& Management, 7(1), 1859849.

Global Ethical Banking.(2021). ISLAMIC FINANCIAL ASSET.Global Ethical Banking.Retrieved on $27^{\text {th }}$ June 2021. Retrieved from: https://www.globalethicalbanking.com/global-islamic-financing-rises-14-6-32-95bn2018/

Haron, R., Abdul Subar, N., \& Ibrahim, K. (2020)."Service quality of Islamic banks: satisfaction, loyalty and the mediating role of trust", Islamic Economic Studies, Vol. 28 No. 1, 3-23.

legislation.gov.uk. (2021).Data Protection Act 1998.Retrieved on $27^{\text {th }}$ June 2021. Retrieved from: https://www.legislation.gov.uk/ukpga/1998/29/contents

My Government.(2021). Managing Non-Syariah Compliant Money.Retrieved on $27^{\text {th }}$ June 2021. Retrieved from: https://www.malaysia.gov.my/portal/content/27678

Pradipta, R. F., Ummah, U. S., \&Dewantoro, D. A. (2018, September). Social Environment of Special Needs in Inclusive Primary School: A Descriptive Research with Phenomenology Approach. In 1st International Conference on Early Childhood and Primary Education (ECPE 2018) (pp. 181-184).Atlantis Press.

statista.com. (2021).Number of Islamic banks worldwide in 2019, by type.Retrieved on $27^{\text {th }}$ June 2021. Retrieved from: https://www.statista.com/statistics/1090895/worldwidenumber-of-islamic-banks-by-type/

Suhartanto, D., Farhani, N. H., \&Muflih, M. (2018). Loyalty Intention towards Islamic Bank: The Role of Religiosity, Image, and Trust. International Journal of Economics \& Management, 12(1).

Utami, C. B., \&Slamet, S. (2021). What Drives Consumer Satisfaction in Using Islamic Financial Technology?. International Journal of Islamic Business Ethics, 6(1), 27-36.

warwick.ac.uk. (2021).inductive or deductive approaches. Retrieved on $27^{\text {th }}$ June 2021. Retrieved from: https://warwick.ac.uk/fac/soc/ces/research/current/socialtheory/maps/when 